\title{
Using a board game "Snake and Lader" to teach speaking descriptive text at the eight grade students of SMPN 2 Wungu
}

\author{
Fathlutfika Trahenar Ratih ${ }^{1}$, Nuri Ati Ningsih ${ }^{2}$, Arri Kurniawan ${ }^{3}$ \\ Universitas PGRI Madiun, Indonesia \\ fathlutfikatrahenarratih@gmail.com
}

\begin{abstract}
This research aims at improving the speaking learning process of the eighth graders of SMP Negeri 2 Wungu through Board Game "Snake and Ladder" in the academic year of 2016/2017 this research used qualitative research because the research wants to describe the implementation of Board Game "Snake and Ladder" in teaching and learning process. This research, the researcher got the data from collecting photos, syllabus, RPP, students' name and students' score. They are used to know how to use, what the advantages and what the disadvantages of teaching speaking using using Board Game "Snake and Ladder" in the eighth graders of junior high school. Then, to collect the data, research need a technique that is called technique of collecting data. There were some instrument used by researcher: observation, interview and documentation. Based on the result of the research, using Board Game "Snake and Ladder" can make students to improve their speaking skill. With this game, the students can make a descriptive text orally. The students also feel confident when they come forwards in front of the class. The students can speak up in front of the class confidently. The students are dared to speak in front of the class because it has been used and the considered classmates as a family. The students are enjoying and having fun. The students are also not bored to be follow the lesson. The students have good respon to the teacher. It makes the students very fun and are not bored because the game in Board Game "Snake and Ladder" is easy to play. Third, using Board Game "Snake and Ladder" this game was easy to implement in the class. This game makes the lesson understood well by the students. It means that by using Board Game media helps the students to comprehend the material clearly and easily because the media facilitate the students to catch the content of the story. Fourth, using Board Game "Snake and Ladder" is this game make students more active to speak up. It means that by using Board Game "Snake and Ladder" in teaching speaking make the students active follow the teaching and learning process. In this research, the researcher give some suggestion. First, the teacher is sugessted to apply various kinds of teaching techniques in teaching speaking. Second, the institutions are suggested to motivated teacher to apply various kinds of teaching techniques. Third, the students are suggested to be more motivated and serious in learning English. And the last, the other researchers are suggested to make further research especially concerning on teaching speaking through the other game or techniques.
\end{abstract}

Keywords: Speaking, Game, Board Game "Snake and Ladder"

\section{INTRODUCTION}

English speaking skill is the most important skill that should be mastered by the students in Junior High School. Based on KTSP curriculum, English is used as a tool to communicate orally and written. The teaching and learning English is targeted the students to reach the functional level of communication that they can communicate orally and written to solve the daily's problems (BSNP, 2006). Therefore, Speaking skill is one of English skills that emphasizes in oral communication. The students can express their ideas and thoughts orally so it helps them to spell the words well. Moreover, based on the basic competence of speaking, the students are expected to express orally the meaning in conversation of transactional (to get thing done) and interpersonal using oral language manner very simple in accurate figure, fluent, and accept for the interaction of with environment closest entangling to act to say: giving direction, describing people/things using adjective, etc. 
Therefore, speaking skill is needed to learn and master by students in Junior High School because it will help them to communicate orally in their daily life.

Based on the result of pre-observation in SMPN 2 Wungu, there are found some indicators of students' difficulties in learning speaking skill. Firstly, they cannot produce sentences fluently even a simple sentence. This difficulty is indicated that there are many fillers when they speak and sometimes use Indonesian expression. Secondly, most of the students cannot produce the sentences grammatically. The students often make some errors in grammar when they are speaking. The students are also lack of vocabulary mastery. It indicates that they often find difficulties in choosing the appropriate words when they want to say something. Thirdly, many of students are lack of speech organization. It indicates that the students must imitate the teacher's sentence example when they produce sentences. Lastly, the students feel bored with learning process because the teacher do not use appropriate or interesting method or media in teaching learning process. So it makes the students not interested to follow the lesson.

Those problems stated above should be solved by using appropriate games. One of them is by using Board Game. Kusrini (2012:4) states that Board Game "Snake And Ladder" is one kind of a board game that widely known by the people. It is a popular game that can facilitate the students to learn language. It means that Board Game is something or an instrument that is used to make the students pay attention and follow the teaching and learning process because board game can make the students more focus in learning. So, they do not feel that they are forced to learn. They also enable the students to acquire new experiences within a foreign language which are not always possible during a typical lesson.

Based on the previously research in journal Retain, by Aisyah in 2014 by the title " The Effectiveness of Using Snakes and Ladders Games to Improve Students' Speaking Ability for Seven Graders in MTSN Mojosari", the research shows that snakes and ladders game is effective media. It can be seen there is increasing mean of experimental group. The increasing mean of experimental group prove that the treatment by using snakes and ladders game could improve the students' speaking skill in speaking class. From the calculation of t-test, it was showed the result of t-value was 8.88, which is higher than t-table (1.98). It showed that there was a significant improvement after conduction of treatment. Thus snakes and ladders game was an effective media to improve students' speaking skills. Then, second journal in JELT, by Aida in 2014 with the title "Using A Board Game "Snake And Ladder" In Teaching Speaking At Junior High School" the result shows that the it is very useful and applicable to be used in speaking class. It will make the students to be more creative in expressing their idea. Besides that, the students will find easier to identify idea on the pictures. They will be able to relate information in the text to their own life. Board game helps teachers and students to present the material effectively.

Two journal above shows that Board Game "Snake and Ladder" is effective media is used to teach speaking skill. Therefore, the researcher is interested to do a research by using Board Game "Snake and Ladder" to teach speaking with the title "Using A Board Game "Snake And Ladder" to Teach Speaking to the Eighth Grade Students of SMPN 2 Wungu".

\section{METHOD}

In this research, the researcher uses qualitative research because the researcher wants to describe the implementation of Board Game "Snake and Ladder" in teaching and learning process. The research observes activities in the class by using description data. The researcher uses the phenomena happen as the data to be analyzed. In order to collecting the data, the researcher needs some instrument used by researcher: first, observation, observations take place as a part of collecting data in research. In this research, the researcher uses non participant because the researcher see all of the process in the class without active in class activity. The researcher uses observation to know 
activities or situation in the class of eighth A grade students of SMP N 2 Wungu. Second, interview. In this research, the researcher interview the English teacher and the three students of A class in SMP $\mathrm{N} 2$ Wungu. The researcher uses unstructured interview in this research because the researcher asks some questions to be the students and they are freely answer the question without thinking the pattern of answer. Third, documentation is written note about the events in the past. In this research, the analysis of document are focused on the chosen documents, include data of the students: list of score, teacher's lesson plan, syllabus. The aim is to contribute the data observation and data interview. The researcher analysis the data uses the interactive analysis techniques which include: First, reduction data, In this research, the researcher selects the data based on important ones and only uses the data related with research of the problem on implementation of Board Game "Snake and Ladder" in teaching speaking to the eighth grade students of SMP N 2 Wungu. Second, displaying data, In this research, after reduction the data, the researcher displays or shows the data of observation, interview, and documentation in description form. The researcher also shows the data in the form of table. Third, conclusion/ verification. it can be concluded that conclusion and verification are used by researcher to conclude and verify the research result. In this step, the researcher sum up the procedures, the advantages, disadvantages and implementation of Board Game "Snake and Ladder" in teaching speaking descriptive text.

\section{RESULT}

After applying the research, the researcher gets some research finding. It can be seen as follow:

1) The Data Implementation of teaching speaking descriptive text by using Board Game "Snake and Ladder" for the eighth grade students of SMPN 2 Wungu

The procedure in implementation of teaching speaking descriptive text by using Board Game "Snake and Ladder" are divided into three steps they are pre activities, whilst activities, post activities. Each step is described as follows:

a) Pre-Activities

Pre-activities is the first activity in the teaching and learning process. In this activities the teacher opens the lesson.

b) Whilst-Activities

Whilst activities is the second and main activity in the teaching and learning process has been done by the teacher. In this activities is the implementation of teaching speaking using Board Game "Snake and Ladder".

c) Post-Activities

Post activities is the last activity in the teaching and learning process. In this activities the teacher closes the lesson.

2) The Data Advantages of teaching speaking descriptive text by using Board Game "Snake and Ladder" for the eighth grade students of SMPN 2 Wungu.

The real data which related with the second problem statement is about the advantages of the implementation of teaching speaking descriptive text by using Board Game "Snake and Ladder" are displayed as follows:

1) Board Game "Snake and Ladder" is technique that very fun, students say that they are very enjoyed and not bored with the lesson.

2) Board Game "Snake and Ladder" can improve the students' motivation in speaking class.

3) Board Game "Snake and Ladder" makes the student can speak in front of the class with confident and students are very excited with the game. 
4) Board Game "Snake and Ladder" was easy to implement in the class and can be understood well by the students.

5) The students are more active to speak English by using Board Game "Snake and Ladder".

3) The Data Disadvantages of teaching speaking descriptive text by using Board Game "Snake and Ladder" for the eighth grade students of SMPN 2 Wungu.

The real data which related with the third problem statement is about the disadvantages in the implementation of teaching speaking descriptive text by using Board Game "Snake and Ladder" are displayed as follows:

1) Board Game "Snake and Ladder" to teach speaking descriptive text there are some students feeling not confident in front of the class..

2) Board Game "Snake and Ladder" doesn't allow the students to improve by making new words. Some students are less mastery of vocabulary and pronounce.

3) Moreover, some students are still difficult to make descriptive text with orally based on the topic. It takes long time in taeching and learning process.

\section{DISCUSSION}

\section{1) The Implementation of Board Game "Snake and Ladder" to teach Speaking Ability for the Eighth Grade of SMPN 2 Wungu.}

In the discussion, the researcher presents the results of discussion between this research this research with the theory of the implementation Board Game "Snake and Ladder" in teaching speaking. The steps of using Board Game "Snake and Ladder" are describe as follows:

a) The teacher explains the material about definition of descriptive text and give explanation about the purpose, generic structure, and language feature of descriptive text.

b) The second activity, the teacher gives a descriptive text paragraph and ask the students to analyze the generic structure and language feature of the text.

c) The teacher introduces a Board Game "Snake and Ladder" media to the students.

d) The teacher explains role to play the game

e) The fifth activity, the teacher asks students to make a groups.

f) The sixth activity, the teacher asks the students play the game.

g) The seventh activity, the teacher asks the students to speak a descriptive text based on the instruction in the Board Game "Snake and Ladder".

h) The eight activity, the teacher helps the students when have difficulty in speaking.

i) The tenth activity, the teacher asks the students to continue the game until get the winner.

\section{CONCLUSION}

The Implementation of Board Game "Snake And Ladder" In Teaching Speaking Descriptive Text To The Eighth Grade Of SMPN 2 Wungu there are there activities. They are pre-activities, whilst-activities, and post-activities. The activities in pre-activities are the teacher gives some kind of opening before go to the teaching and learning process. The activities in whilst-activities are the implementation of teaching speaking descriptive text by using Board Game "Snake and Ladder". Then, in the post-activities includes review and conclusion the material to the students in the teaching and learning process. Those activities are appropriate with the lesson plan (RPP), checklist of observation, and previous research of teaching speaking using Board Game "Snake and Ladder" by Aida (2014: 21-23), in Chapter II although the teacher changes, adds, and throws some activities.

The Advantages Of The Use Of Board Game "Snake And Ladder" In Teaching Speaking Descriptive Text To The Eighth Grade Of SMPN 2 Wungu. There are some advantages of the implementation of teaching speaking descriptive text by using Board Game "Snake and Ladder" for the eighth grade students of SMPN 2 Wungu in the schooling year of 2016/2017. First, Board Game 
"Snake and Ladder" are to make improvement for student's speaking skill and make the students confident to speak up. Second, make students have fun, enjoy, excited, and not bored with the lesson. Third, Board Game "Snake and Ladder" is very easy and can be understood by the students. And the last, Board Game "Snake and Ladder" makes students more active to speak English.

The Disadvantages Of The Use Of Board Game "Snake And Ladder" In Teaching Speaking Descriptive Text To The Eighth Grade Of SMPN 2 Wungu. There are some disadvantages of the implementation of teaching speaking descriptive text by using Board Game "Snake and Ladder" for the eighth grade students of SMPN 2 Wungu in the schooling year of 2016/2017. First, some students less mastery of vocabulary and pronounce. Second, some students have difficult to make descriptive text orally. And the last, needs more time allocated and make the teaching situation uncontrolled.

\section{REFERENCES}

Ary, D., Jacobs, L. C., Sorensen, C., \&Razavieh, A. (2010).Introduction to Research in Education. $8^{\text {th }}$ Edition.United States Copyright Act.

Aida, S., \& Rusdi, N. (2014). Using A Board Game "Snake And Ladder" In Teaching Speaking At Junior High School. JELT Journal 2(2), 16-24

Aisyah, N. (2014). The Effectiveness Of Using Snake and Ladder Games to Improve Students' Speaking Ability For Seven Graders in MTSN Mojosari. RETAIN Journal. 01(01),1-6.

Bogdan and Biklen. (2007). Qualitative Research Methods for the Social Sciences. Bostom: Pearson Education.

Brown, H. Douglas. (2001). Teaching by Principles: An Interactive Approach to Language Pedagogy. $2^{\text {nd }}$ Edition. New York: Addison Wesley Longman, Inc.

Brown, H. Douglas. (2004). Language Assessment: Principles and Classroom Practices. New York: Pearson Education.

Board Games Of Grade Viii Of Smp N 13 Yogyakarta In The Academic Year Of 2013/2014. Tesis tidak diterbitkan. Yogyakarta: English Education Study Program English Education Department Faculty Of Languages And Arts Yogyakarta State University, 2015, 1-267.'

Chang, S., \& Cogwell, J. (2008). Using Board Games in the Language Classroom. TESOL Journal, 2(008), 1-5.

Cresswell, John. W. (2009). Research Design: Qualitative, Quantitative, and Mixed Approaches. $3^{\text {rd }}$ Edition.United States of America: Sage Publications, Inc.

Hadfield, J. \& Hadfield, C. (2008). Introduction to Teaching English. Oxford University Press.

Harmer, Jeremy. (1998). The Effectiveness Of Using Snakes And Ladders Games To Improve Students' Speaking Ability For Seven Graders In Mtsn Mojosari. RETAIN Journal, 01(01),0-6 
Harmer, Jeremy. (2007). The Practice of English Language Teaching. $4^{\text {th }}$ Edition. Harlow: Pearson Education Limited.

John, Langan. (2005). College Writing Skills. New York: McGraw-Hill.

Lia, A., N. (2001). Improving Students' Speaking Skills Through. Speaking JELT Journal 2(2), 16-24

Miles, et al. (2014). Qualitative Data Analysis: A Methods Sourcebook. $3^{\text {th }}$ Edition. United States of America: Sage Publications, Inc.

Nunan, D. (2003). Practical English Language Teaching. New York: The McGraw Hill.

Richards, J.C. \&Renandya, W.A. (2002). Methodology in Language Teaching: An Anthology of Current Practice. Cambridge: United Kingdom.

Smaldino, Sharon ,Russel, \&Molenda, M. (2005). Instructional Technology and Media for Learning. Pearson: Merrill Prentice Hall.

Wahyuni, Sari. (2012). Qualitative Research Method: Theory and Practice. Jakarta: SalembaEmpat.

Yin, Robert K. (2011). Qualitative Research from Start to Finish. New York: The Guilford Press. 